Artikel Penelitian

\title{
Potensi Yogurt Rosella Probiotik Lactobacillus plantarum IIA-1A5 atau Lactobacillus fermentum B111K dalam Mengasimilasi Kolesterol
}

\author{
Potency of Yogurt Roselle Probiotic Lactobacillus plantarum IIA-1A5 or Lactobacillus fermentum B111K in \\ Assimilating Cholesterol \\ Asti Yosela Oktaviana ${ }^{1}$, Irma Isnafia Arief $^{2}$, Irmanida Batubara ${ }^{3}$ \\ ${ }^{1}$ Program Studi IImu Produksi dan Teknologi Peternakan, Fakultas Peternakan, Institut Pertanian Bogor, Bogor \\ ${ }^{2}$ Departemen IImu Produksi dan Teknologi Peternakan, Fakultas Peternakan, Institut Pertanian Bogor, Bogor \\ ${ }^{3}$ Departemen Kimia, Fakultas Matematika dan IImu Pengetahuan Alam, Institut Pertanian Bogor, Bogor \\ *Korespondensi dengan penulis (irma_isnafia@yahoo.com). \\ Artikel ini dikirim pada tanggal 25 Mei 2018 dan dinyatakan diterima tanggal 29 Agustus 2018. Artikel ini juga dipublikasi secara online melalui \\ https://ejournal2.undip.ac.id/index.php/jatp. Hak cipta dilindungi undang-undang. Dilarang diperbanyak untuk tujuan komersial. \\ Diproduksi oleh Indonesian Food Technologists® @2018
}

\begin{abstract}
Abstrak
Hiperkolesterolemia merupakan salah satu faktor penyebab penyakit kardiovaskular. Altenatif untuk mencegah hiperkolesterolemia adalah mengonsumsi yogurt rosella probiotik hipokolesterolemik. Bakteri Lactobacillus bulgaricus dan Streptococcus thermophilus di dalam yogurt tidak termasuk bakteri probiotik. Oleh karena itu, perlu ditambahkan bakteri asam laktat probiotik Lactobacillus plantarum IIA-1A5 dan Lactobacillus fermentum B111K yang memiliki kemampuan dalam mengasimasi kolesterol. Tujuan penelitian untuk mengevaluasi karakteristik dan kemampuan yogurt rosella probiotik dengan menggunakan $L$. plantarum IIA-1A5 dan L. fermentum B111K dalam mengasimilasi kolesterol secara in vitro dengan lama penyimpanan berbeda. Perlakuan yang dilakukan dalam penelitian ini adalah P1 : Yogurt dengan bakteri L. bulgaricus dan S. thermophilus, P2 : Yogurt rosella dengan $L$. bulgaricus dan $S$. thermophilus, P3 : Yogurt rosella dengan bakteri $L$. bulgaricus, $S$. thermophilus dan L. plantarum IIA-1A5, P4 : Yogurt rosella dengan bakteri L. bulgaricus, S. thermophilus dan L. fermentum B111K. Hasil penelitian menunjukkan bahwa bakteri $L$. plantarum IIA-1A5 dan $L$. fermentum memberikan pengaruh nyata $(P<0,05)$ terhadap nilai viskositas, aktivitas air, total asam tertitrasi (TAT) selama penyimpanan 15 hari. Penggunaan bakteri $L$. plantarum IIA-1A5 dan $L$. fermentum $B 111 \mathrm{~K}$ tidak memberikan pengaruh yang nyata $(P>0,05)$ terhadap nilai total bakteri asam laktat (BAL) tetapi lama penyimpanan 15 hari memberikan pengaruh nyata $(P<0,05)$. Selama 15 hari penyimpanan suhu dingin, kualitas fisik, kimiawi dan mikrobiologi yogurt masih baik dan layak untuk dikonsumsi. Kesimpulannya, kemampuan asimilasi kolesterol pada yogurt rosella probiotik menggunakan $L$. plantarum IIA-1A5 dan L. fermentum B111K lebih tinggi dibandingkan yogurt dan yogurt rosella serta terjadi penurunan kemampuan asimilasi pada keempat perlakuan yogurt selama penyimpanan 15 hari.
\end{abstract}

Kata kunci : yogurt rosella, bakteri probiotik, lama penyimpanan, karakteristik, asimilasi kolesterol.

\begin{abstract}
Hypercholesterolaemia is one of factors causing cardiovascular disease. Alternative to prevent hypercholesterolemia is to consume yogurt roselle probiotic using Lactobacillus plantarum IIA-1A5 and Lactobacillus fermentum B111K which has the ability to assimilate cholesterol. The objective of the study was to evaluate the characteristics and abilities of probiotic rosella yogurt using $L$. plantarum IIA-1A5 and L. fermentum B111K in assimilating cholesterol by in vitro analysis with different storage times. Treatments of this research were $P 1=p l a i n$ yogurt, $P 2=$ roselle yogurt, $P 3=$ roselle yogurt with $L$. plantarum IIA-1A5, and P4: rosella yogurt with $L$. fermentum $B 111 K$. The results showed that $L$. plantarum IIA-1A5 and $L$. fermentum had significant effect $(P<0.05)$ on viscosity, water activity, total titrated acids (TAT) during 15 days storage. The use of L. plantarum IIA-1A5 and L. fermentum $B 111 \mathrm{~K}$ bacteria did not give significant effect $(P>0.05)$ to the total value of lactic acid bacteria (BAL) until 15 days of storage. As conclusion, 15 days of storage exhibited the product that were still good and worth for consumption and rosella probiotic yogurt provided much better assimilation in cholesterol.
\end{abstract}

Keyword : yogurt rosella, probiotic bacteria, storage time, characteristic, cholesterol assimilation .....

\section{Pendahuluan}

World Health Organization atau WHO (2017) menempatkan penyakit kardiovaskular pada urutan pertama sebagai penyebab kematian terbesar dunia. Sebanyak $31 \%$ kematian diseluruh dunia disebabkan oleh penyakit kardiovaskular. Salah satu faktor resiko penyakit kardiosvaskular yaitu hiperkolesterolemia yang merupakan suatu keadaan dimana konsentrasi kolesterol di dalam darah melebihi batas normal atau melebihi nilai rujukan (Freed, 1994). Faktor yang menyebabkan hiperkolesterolemia antara lain gaya hidup masyarakat yang mulai berubah seperti mengkonsumsi makanan yang tinggi lemak (Setiawan et al., 2016). Salah satu alternatif yang aman untuk mencegah penyakit kardiosvaskular adalah dengan mengubah gaya hidup sehat dengan mengonsumsi 
makanan dan minuman fungsional yang mampu mengontrol jumlah kolesterol dalam darah seperti yogurt probiotik yang bersifat hipokolesterolemik. Yogurt merupakan susu fermentasi yang diolah menggunakan bakteri asam laktat $L$. bulgaricus dan $S$. thermophilus (Rose, 1989). Namun, kedua bakteri tersebut tidak mampu bertahan melewati saluran pencernaan untuk tetap hidup di usus. Oleh karena itu, agar memiliki efek fungsional bagi kesehatan perlu ditambahkan bakteri asam laktat probiotik yang memiliki potensi untuk meningkatkan kesehatan dan nutrisi. Bakteri asam laktat dikategorikan sebagai probiotik apabila bakteri tersebut mampu bertahan melewati lambung dan usus halus serta toleran terhadap suasana asam dan adanya asam empedu (Tuomola et al., 2001; Bourlioux et al., 2003).

Bakteri asam laktat $L$. plantarum IIA-1A5 merupakan salah satu bakteri asam laktat probiotik yang telah berhasil diisolasi oleh Arief et al., (2015) yang berasal dari daging sapi segar asli Indonesia bangsa Peranakan Ongole dan L. fermentum B111K merupakan salah satu bakteri asam laktat asal dangke dari Enrekang, Sulawesi Selatan yang diisolasi oleh Syah et al., (2017). Kedua bakteri tersebut telah diteliti kemampuannya dalam mengasimilasi kolesterol oleh Burhan et al., (2017) sehingga diperoleh bahwa bakteri asam laktat probiotik $L$. plantarum IIA-1A5 dan $L$. fermentum B111K memiliki kemampuan dalam mengasimilasi kolesterol melalui penyerapan dan pengikatan kolesterol.

Penelitian mengenai yogurt susu sapi dalam menurunkan kolesterol telah dilakukan oleh Oktavia et al., (2017) dengan memberikan yogurt sinbiotik tepung pisang tanduk dan diberikan kepada tikus wistar yang kemudian diperoleh hasil bahwa terjadi penurunan kadar trigliserida, kolesterol total, kolesterol LDL, dan peningkatan kolesterol HDL. Selain itu, Ishmayana et al., (2015) melakukan penelitian pengaruh konnsumsi yogurt yang dibuat dengan dua kultur bakteri dan tiga kultur bakteri terhadap kadar kolesterol serum darah tikus dan diperoleh bahwa yogurt yang dibuat dengan tiga bakteri ( $S$. thermophillus, $L$. bulgaricus dan $L$. acidophilus) menunjukkan efek penurunan kadar kolesterol serum darah yang lebih baik dibandingkan yogurt dua bakteri (S. thermophillus dan L. bulgaricus).

Selain menggunakan bakteri asam laktat probiotik, ekstrak bunga rosella (Hibiscuss sabdariffa L) dapat ditambahkan dalam pembuatan yogurt seperti pada penelitian yang dilakukan oleh Suharto et al., (2017) yang telah melakukan penelitian yogurt rosella susu sapi dan susu kambing dengan menggunakan bakteri asam laktat probiotik Lactobacillus dan diperoleh bahwa yogurt rosella susu kambing memiliki antioksidan yang tertinggi. Yogurt rosella susu kambing $L$. acidophilus IIA-2B4 terbukti memiliki potensi sebagai antihipertensi dan antimikroba yogurt (Arief et al., 2016 dan Hanifah et al., 2016). Ekstrak kelopak bunga rosella juga dapat digunakan sebagai sumber fenolik dan antioksidan yang dapat meningkatkan laju pembuangan kolesterol dalam bentuk asam empedu melalui usus halus (Winarti, 2010). Menurut beberapa penelitian, bunga rosella berpengaruh terhadap kadar kolesterol total serum tikus Sprague-dawley hiperkolesterolemik. Penelitian mengenai yogurt yang mampu menurunkan kolesterol dan potensi yogurt rosella sebagai antioksidan, antihipertensi dan antimikroba, telah banyak dilakukan, namun belum ada penelitian mengenai potensi yogurt rosella probiotik yang dapat menurunkan kolesterol melalui asimilasi kolesterol secara in vitro. Oleh karena itu, perlu dilakukan penelitian mengenai yogurt rosella probiotik dalam mengasimilasi kolesterol dengan menggunakan bakteri asam laktat probiotik $L$. plantarum IIA-1A5 dan $L$. fermentum B111K.

Penelitian ini bertujuan untuk mengevaluasi karakteristik fisik, kimia, mikrobiologi dan kemampuan yogurt rosella probiotik susu kambing dengan menggunakan L. plantarum IIA-1A5 dan L. fermentum $\mathrm{B} 111 \mathrm{~K}$ dalam kemampuanya untuk mengasimilasi kolesterol secara in vitro dengan lama penyimpanan yang berbeda. Manfaat dari penelitian ini adalah memberikan informasi mengenai karakteristik dan kemampuan yogurt rosella probiotik susu kambing dengan menggunakan $L$. plantarum IIA-1A5 dan $L$. fermentum $\mathrm{B} 111 \mathrm{~K}$ dalam mengasimilasi kolesterol secara in vitro.

\section{Materi dan Metode \\ Materi}

Bahan-bahan yang digunakan dalam penelitian ini adalah susu kambing, bunga rosella (Hibiscus sabdariffa) kering. Kultur yogurt yang digunakan antara lain Lactobacillus delbruecki subsp bulgaricus RRAM01, S. thermophilus RRAM-01, deMann Rogosa Sharpe Broth (MRSB) (Oxoid, Ltd., Inggris), Buffer Pepton Water (BPW) (Oxoid, Ltd., Inggris), Yeast Ekstrak (YE) (Oxoid, Ltd., Inggris), O-phthalaldehyde (Oxoid, Ltd., Inggris), fenolftalein (Merck), kolesterol PEG 600 (Sigma aldrich), heksana, etanol, asam asetat dan $\mathrm{KOH}$. Peralatan yang digunakan dalam penelitian ini antara lain inkubator, autoclave, laminar, hand sealer, viscotester, $\mathrm{pH}$ meter Schott, $\mathrm{a}_{\mathrm{w}}$ meter Novasina, dan buret.

\section{Metode}

Penelitian ini dilaksanakan dari bulan Oktober 2017 hingga Februari 2018. Penelitian ini meliputi proses peremajaan bakteri, pembuatan ekstrak rosella, pembuatan yogurt dan pengujian karakteristik fisik, kimia, dan mikrobiologi antara lain viskositas, aktivitas air, total asam tertitrasi (TAT), total bakteri asam laktat (BAL) serta pengujian asimilasi kolesterol yogurt. Rancangan percobaan yang digunakan pada penelitian ini adalah rancangan acak kelompok faktorial $4 \times 4$ dengan 4 perlakuan dan 3 ulangan. Faktor pertama yaitu perlakuan yogurt tanpa penambahan ekstrak rosella (Hibiscus sabdariffa) ( $\mathrm{Y})$, yogurt dengan penambahan ekstrak rosella (YR), yogurt ekstrak rosella probiotik dengan L. plantarum IIA-1A5 (YRPP) dan yogurt rosella probiotik dengan $L$. fermentum $B 111 \mathrm{~K}$ (YRPF) dan faktor kedua yaitu lama penyimpanan $0,5,10$, dan 15 hari. 


\section{Peremajaan Starter Bakteri}

Peremajaan starter dilakukan dengan cara menginokulasikan kultur yogurt sebanyak 10\% (v/v) ke dalam susu yang telah disterilisasi terlebih dahulu pada autoclave dengan suhu $115^{\circ} \mathrm{C}$ selama tiga menit. Selanjutnya dilakukan inkubasi pada suhu $37^{\circ} \mathrm{C}$ selama 18 jam sampai terbentuk koagulasi sehingga diperoleh kultur kerja.

\section{Pembuatan Ekstrak Rosella}

Pembuatan ektrak rosella dilakukan dengan menggunakan modifikasi metode Tsai et al., (2008) yaitu bunga rosella kering dihaluskan dan diayak menggunakan ayakan 60 mesh hingga diperoleh rosella dalam bentuk tepung. Tepung rosella dilarutkan menggunakan akuades steril dengan perbandingan $20 \mathrm{~g}$ : $100 \mathrm{ml}$ dan dipasteurisasi pada suhu $63-65^{\circ} \mathrm{C}$ selama 30 menit. Setelah pasteurisasi, larutan rosella disaring menggunakan kertas saring dan dilakukan evaporasi. Kemudian dilakukan pengeringan beku menggunakan freeze dryer sehingga diperoleh ekstrak rosella dalam bentuk serbuk. Ekstrak disimpan dalam freezer hingga digunakan.

\section{Pembuatan Yogurt}

Metode yang digunakan dalam pembuatan yogurt adalah menggunakan metode Donkor et al., (2006). Susu kambing yang akan digunakan dipanaskan selama 30 menit pada suhu $85-90^{\circ} \mathrm{C}$ dan diturunkan suhunya sampai suhu mencapai $40-45^{\circ} \mathrm{C}$. Susu yang telah dipanaskan ditambahkan starter bakteri dengan populasi $1 \times 10^{7} \mathrm{CFU} / \mathrm{ml}$. Perlakuan kontrol tidak ditambahkan bakteri probiotik. Setelah dilakukan inokulasi dilakukan inkubasi selama 16 jam pada suhu $37^{\circ} \mathrm{C}$ sampai terbentuk koagulasi. Ditambahkan ekstrak rosella sebanyak $1 \%$ (b/v) dari volume susu. Selanjutnya yogurt disimpan dalam suhu dingin dengan waktu penyimpanan berbeda untuk kemudian dilakukan analisis.

\section{Analisis Viskositas Yogurt}

Pengukuran viskositas dilakukan menggunakan alat Rotational Viscotester (Rion VT-04F, Jepang) dengan metode yang digunakan sesuai petunjuk perusahaan Rion yaitu dengan memasukkan $100 \mathrm{ml}$ sampel ke dalam tempat yang telah tersedia dalam rotational viscometer, kemudian rotor dicelupkan ke dalam sampel dan dibiarkan berputar sampai jarum skala petunjuk berhenti pada skala tertentu. Apabila jarum skala petunjuk telah berhenti dan terbaca skala maka sekala tersebut menunjukkan nilai viskositas dari sampel dengan satuan viskositasnya adalah dPa.s (Rion, 2015).

\section{Aktivitas Air $\left(\mathrm{a}_{\mathrm{w}}\right)$}

Pengukuran aktivitas air dilakukan dengan menggunakan $a_{w}$ meter Novasina ms1 Set-aw dengan metode yang digunakan sesuai petunjuk perusahaan. Terlebih dahulu, alat $a_{w}$ meter ini dilakukan kalibrasi dengan menggunakan $\mathrm{NaCl}$ jenuh yang memiliki nilai $\mathrm{a}_{\mathrm{w}}$ 0,75 dan $\mathrm{BaCl}_{2}$ pada $\mathrm{a}_{\mathrm{w}} 0,90$. Setelah itu, sampel yogurt dimasukkan ke dalam chamber $a_{w}$ meter yang tersedia dan dilakukan penutupan pada chamber tersebut dan selang beberapa saat, dapat terlihat angka yang stabil yang kemudian catat angka tetap sebagai nilai $a_{w}$ (Novasina, 2010).

Nilai $\mathrm{pH}$

Pengukuran nilai $\mathrm{pH}$ dilakukan dengan menggunakan $\mathrm{pH}$ meter. Kalibrasi dilakukan dengan menggunakan larutan buffer pada $\mathrm{pH} 4,01$ dan $\mathrm{pH} 7,01$. Pengukuran dilakukan dengan cara mencelupkan elektroda $\mathrm{pH}$ meter ke dalam $10 \mathrm{ml}$ sampel dan ditunggu sampai $\mathrm{pH}$ meter menunjukkan angka yang stabil (AOAC, 2005).

\section{Nilai Total Asam Tertitrasi}

Pengukuran nilai total tertitrasi dilakukan dengan menggunakan sampel yogurt sebanyak $10 \mathrm{ml}$ lalu ditambahkan tiga tetes fenolftalein yang kemudian dilakukan titrasi menggunakan larutan $\mathrm{NaOH}(0,1 \mathrm{~N})$ sampai terbentuk warna merah muda dan saat dihomogenkan warna tersebut menjadi tidak hilang. Perhitungan persentase nilai total asam tertitrasi (TAT) ditentukan dari perkalian normalitas titran, volume titran, dan berat equivalen asam yang kemudian dibagi dengan volume sampel dikalikan 10 (Nielsen, 2003)

\section{Total Bakteri Asam Laktat}

Metode yang digunakan dalam penghitungan total bakteri asam laktat adalah metode Pelezar et al., (2007) yaitu ke dalam tabung reaksi yang berisi $225 \mathrm{ml}$ larutan BPW dimasukkan $25 \mathrm{ml}$ sampel yogurt sesuai perlakuan dan diaduk menggunakan spatula hingga diperoleh pengenceran $1\left(\mathrm{P}^{-1}\right)$. Selanjutnya dari $\mathrm{P}^{-1}$ diambil $1 \mathrm{ml}$ untuk dilarutkan kedalam larutan pengencer $9 \mathrm{ml}$ BPW sehingga diperoleh $\mathrm{P}^{-2}$, hal yang sama dilakukan sampai memperoleh pengenceran $9\left(\mathrm{P}^{-9}\right)$. Kemudian dilakukan inokulasi dengan metode pour plate dimana sebanyak 1 $\mathrm{ml}$ sampel yogurt masing-masing perlakuan pada pengenceran ke enam $\left(\mathrm{P}^{-6}\right)$ sampai pengenceran ke sembilan $\left(\mathrm{P}^{-9}\right)$ dipindahkan ke dalam cawan petri untuk kemudian dilakukan inokulasi atau pencampuran dengan $15 \mathrm{ml}$ media MRSA (de man rogosa sharpe agar). Setelah inokulasi dilakukan inkubasi pada cawan tersebut selama 48 jam dan akan terbentuk koloni bakteri asam laktat yang kemudian dilakukan penghitungan dengan menggunakan metode standar plate count (SPC).

\section{Kemampuan Asimilasi Kolesterol Yogurt}

Uji kemampuan asimilasi kolesterol yogurt menggunakan metode modifikasi dari TomaroDuchesneau (2014), dengan menggunakan kolesterol PEG 600 sebanyak $100 \mu \mathrm{g} / \mathrm{ml}$ yang dimasukkan ke dalam sampel dan diinkubasi selama 24 jam pada suhu $37^{\circ} \mathrm{C}$. Kemudian dilakukan sentrifugasi dengan kecepatan $537,60 \mathrm{~g}$ selama 10 menit pada suhu $4^{\circ} \mathrm{C}$ hingga diperoleh bagian supernatan. Supernatan yang diperoleh kemudian ditambahkan kedalam $500 \mu \mathrm{KOH}$ $33 \%$ dan $1 \mathrm{ml}$ etanol yang dikocok menggunakan vortex selama 1 menit dan diinkubasi selama 15 menit pada suhu $37^{\circ} \mathrm{C}$ lalu dibiarkan pada suhu ruang selama 10 
menit. Selanjutnya ditambahkan $1 \mathrm{ml} \mathrm{H}_{2} \mathrm{O}$ dan $1,5 \mathrm{ml}$ heksana dan dikocok dengan menggunakan vortex selama 1 menit. Sebanyak $500 \mu$ fase larutan heksana kemudian dipindahkan ke dalam tabung baru dan dilakukan evaporasi menggunakan gas nitrogen. Ke dalam sampel yang telah kering ditambahkan $1 \mathrm{ml} 50$ $\mathrm{mg} / \mathrm{dl}$ pereaksi o-phthalaldehyde dan $250 \mu \mathrm{l}$ asam sulfat pekat $\left(\mathrm{H}_{2} \mathrm{SO}_{4}\right)$, lalu dikocok dengan vortex selama 1 menit yang kemudian dilakukan inkubasi selama 20 menit pada suhu ruang. Setelah itu, larutan dibaca absorbansinya dengan menggunakan spektrofotometer dengan panjang gelombang $570 \mathrm{~nm}$.

Nilai asimilasi kolesterol ditentukan berdasarkan kurva standar kolesterol dengan nilai absorbansi sampel menggunakan konsentrasi kolesterol 3,$91 ; 7,81 ; 15,63$ ; 31,$25 ; 62,5 ; 125 \mu \mathrm{l} / \mathrm{ml}$. Nilai asimilasi kolesterol ditentukan dari pengurangan nilai kolesterol sebelum inkubasi dengan nilai sampel yogurt sesudah inkubasi 24 jam dalam satuan $\mu \mathrm{l} / \mathrm{ml}$. Persentase kolesterol yang terasimilasi dihitung dari pembagian nilai asimilasi kolesterol dengan nilai kolesterol 0 jam.

\section{Analisis Statistik}

Data yang diperoleh, lalu dianalisis dengan metode One-Way ANOVA yang menggunakan Statistical Analysis System (SAS). Jika ada perbedaan yang nyata maka dilakukan uji Least squares means (LS Means).

\section{Hasil dan Pembahasan}

Karakteristik Susu dan Ekstrak Rosella

Nilai kandungan susu kambing peranakan etawa yang digunakan meliputi lemak, protein, laktosa, dan berat jenis pada susu kambing yang masing-masing sebesar $8,77,3,66,3,50 \%$, dan $1,023 \mathrm{~g} / \mathrm{cm}^{3}$, berat kering tanpa lemak diperoleh sebesar 7,73, sedangkan kandungan ekstrak rosella yang digunakan, menunjukkan nilai $\mathrm{pH}$ sebesar 2,49, kadar air sebesar $16,36 \%$, dan nilai rendemen sebesar $19,25 \%$.

\section{Analisis Viskositas Yogurt}

Berdasarkan pada Tabel 1, nilai viskositas adalah nyata dipengaruhi oleh jenis yogurt dan lama penyimpanan serta menunjukkan adanya interaksi antar keduanya $(P<0,05)$. Berdasarkan parameter nilai viskositas selama penyimpanan 0 hari, jenis yogurt $Y$ memiliki nilai viskositas yang lebih tinggi dari ketiga perlakuan lain yang disebabkan karena tidak adanya penambahan ekstrak rosella. Ekstrak rosella kering ditambahkan pada yogurt pada saat setelah inkubasi dengan cara pengadukan guna melarutkan ekstrak rosella ke dalam yogurt. Pengadukan tersebut menyebabkan gumpalan yang terbentuk pada yogurt menjadi pecah sehingga mempengaruhi viskositas yogurt. Chairunnisa et al., (2017) menyatakan bahwa yogurt mengalami perubahan tekstur dan viskositas apabila setelah inkubasi dilakukan pengadukan.

Selama penyimpanan, terjadi peningkatan nilai viskositas pada keempat jenis perlakuan yogurt. Penyimpanan 5 hari menunjukkan nilai viskositas yang tertinggi yang diperoleh pada perlakuan jenis yogurt rosella probiotik $L$. plantarum IIA-1A5 (YRPP) yang disebabkan karena keasaman yang dihasilkan selama proses fermentasi. Keasaman tersebut juga berdampak pada penurunan nilai $\mathrm{pH}$ yang mengakibatkan meningkatnya nilai viskositas yogurt rosella probiotik $L$.

Tabel 1 Nilai viskositas yogurt (dPa.s) selama penyimpanan suhu dingin

\begin{tabular}{lcccc}
\hline $\begin{array}{l}\text { Lama } \\
\text { Penyimpanan } \\
\text { Hari ke- }\end{array}$ & Y & YR & YRPP & YRPF \\
\cline { 2 - 5 } & & & & \\
\hline 0 & $2,35 \pm 0,21^{\mathrm{ef}}$ & $1,73 \pm 0,18^{\mathrm{g}}$ & $2,16 \pm 0,05^{\mathrm{f}}$ & $2,13 \pm 0,02^{\mathrm{f}}$ \\
5 & $2,50 \pm 0,20^{\mathrm{de}}$ & $2,40 \pm 0,26^{\text {ef }}$ & $3,24 \pm 0,24^{\mathrm{a}}$ & $2,83 \pm 0,13^{\mathrm{bcd}}$ \\
10 & $3,11 \pm 0,14^{\mathrm{ab}}$ & $3,08 \pm 0,09^{\mathrm{abc}}$ & $3,03 \pm 0,14^{\mathrm{abc}}$ & $2,76 \pm 0,14^{\mathrm{cd}}$ \\
15 & $3,05 \pm 0,08^{\mathrm{abc}}$ & $3,10 \pm 0,36^{\mathrm{ab}}$ & $3,13 \pm 0,31^{\mathrm{ab}}$ & $2,61 \pm 0,05^{\mathrm{de}}$ \\
\hline
\end{tabular}

$\underline{T a b e l} 2$ Nilai $a_{w}$ yogurt selama penyimpanan suhu dingin

\begin{tabular}{lcccc}
\hline \multirow{2}{*}{$\begin{array}{l}\text { Penyimpanan } \\
\text { Hari ke- }\end{array}$} & Y & YR & YRPP & YRPF \\
\cline { 2 - 4 } & & & & \\
\hline 0 & $0,866 \pm 0,002^{\mathrm{ab}}$ & $0,849 \pm 0,006^{\mathrm{c}}$ & $0,842 \pm 0,008^{\mathrm{cd}}$ & $0,841 \pm 0,004^{\mathrm{cd}}$ \\
5 & $0,854 \pm 0,003^{\mathrm{bc}}$ & $0,846 \pm 0,003^{\mathrm{cd}}$ & $0,834 \pm 0,002^{\mathrm{de}}$ & $0,843 \pm 0,006^{\mathrm{cd}}$ \\
10 & $0,872 \pm 0,001^{\mathrm{a}}$ & $0,867 \pm 0,006^{\mathrm{ab}}$ & $0,826 \pm 0,010^{\mathrm{e}}$ & $0,838 \pm 0,003^{\mathrm{de}}$ \\
15 & $0,842 \pm 0,006^{\mathrm{cd}}$ & $0,838 \pm 0,011^{\mathrm{de}}$ & $0,831 \pm 0,000 \mathrm{~d}^{\mathrm{e}}$ & $0,844 \pm 0,022^{\mathrm{cd}}$ \\
\hline
\end{tabular}

Tabel 3 Nilai $\mathrm{pH}$ yogurt selama penyimpanan suhu dingin

\begin{tabular}{lccccc}
\hline $\begin{array}{l}\text { Lama } \\
\text { Penyimpanan } \\
\text { Hari ke- }\end{array}$ & Y & YR & YRPP & Rata-rata \\
\cline { 2 - 5 } & & & & YRPF & \\
\hline 0 & $4,33 \pm 0,05$ & $3,98 \pm 0,02$ & $3,76 \pm 0,03$ & $3,88 \pm 0,05$ & $3,99 \pm 0,04^{\mathrm{a}}$ \\
5 & $4,17 \pm 0,08$ & $3,84 \pm 0,00$ & $3,66 \pm 0,02$ & $3,83 \pm 0,06$ & $3,87 \pm 0,04^{\mathrm{b}}$ \\
10 & $4,12 \pm 0,02$ & $3,82 \pm 0,00$ & $3,65 \pm 0,05$ & $3,79 \pm 0,01$ & $3,85 \pm 0,02^{\mathrm{b}}$ \\
15 & $4,15 \pm 0,01$ & $3,82 \pm 0,00$ & $3,63 \pm 0,02$ & $3,78 \pm 0,00$ & $3,85 \pm 0,01^{\mathrm{b}}$ \\
\hline Rata-rata & $4,19 \pm 0,04^{\mathrm{a}}$ & $3,86 \pm 0,01^{\mathrm{b}}$ & $3,68 \pm 0,03^{\mathrm{d}}$ & $3,82 \pm 0,03^{\mathrm{c}}$ &
\end{tabular}

Keterangan untuk Tabel 1-3: Angka pada kolom atau baris yang sama dan diikuti huruf berbeda menunjukkan berbeda nyata $(P<0,05)$. $Y$ adalah yogurt tanpa penambahan ekstrak rosella (Hibiscus sabdariffa), YR adalah yogurt dengan penambahan ekstrak rosella, YRPP adalah yogurt ekstrak rosella probiotik dengan L.plantarum IIA-1A5, dan YRPF adalah yogurt rosella probiotik dengan $L$. fermentum B111K. 
plantarum IIA-1A5 atau YRPP sebagai akibat kondisi asam pada yogurt yang menyebabkan protein susu, yaitu kasein berubah struktur dan terdenaturasi membentuk gumpalan (Burhan, 2008). Selain itu, terbentuknya asam laktat oleh bakteri asam laktat menyebabkan peningkatan total asam sehingga kasein mengalami koagulasi pembentuk gel yang menyebabkan viskositas meningkat (Wahyudi et al., 2008).

Nilai viskositas tertinggi dicapai pada penyimpanan 10 sampai 15 hari yang diperoleh dari perlakuan yogurt $\mathrm{Y}, \mathrm{YR}$, dan YRPP yang disebabkan adanya eksopolisdakarida (EPS) yang dihasilkan oleh bakteri asam laktat (BAL). Eksopolisakarida (EPS) merupakan polimer polisakarida yang diproduksi oleh bakteri asam laktat dalam bentuk lendir sebagai produk metabolit sekunder yang dihasilkan saat lingkungan pertumbuhannya kurang menguntungkan seperti saat penyimpanan atau pada saat pertumbuhan bakteri asam laktat telah berhenti (Malaka, 2010). Eksopoliskarida dapat berperan sebagai stabilisator, pengental, emulsifier, pembentuk gel, dan memiliki kemampuan mengikat air yang baik. S. thermophilus, L. bulgaricus, dan L. plantarum juga dinilai dapat meningkatkan viskositas yogurt disebabkan karena kultur ini memproduksi eksopolisdakarida (Malaka, 2010; Mannab dan Awwaly, 2007).

\section{Aktivitas air}

Aktivitas air $\left(a_{w}\right)$ adalah jumlah air bebas pada produk pangan yang dapat digunakan oleh mikroba untuk pertumbuhannya. Semakin tinggi nilai $a_{w}$ maka semakin tinggi pula kemungkinan kerusakan dari produk pangan akibat adanya aktivitas mikroorganisme yang tidak dikehendaki. Aktivitas air merupakan salah satu faktor yang dapat mempengaruhi kerusakan pangan karena aktivitas air dapat menggambarkan kebutuhan bakteri akan air. Nilai $a_{w}$ minimum untuk pertumbuhan bakteri adalah 0,90 (Belitz et al., 2009). Nilai $a_{w}$ nyata dipengaruhi oleh perlakuan jenis yogurt dan lama penyimpanan, serta interaksi antar keduanya $(P<0,05)$. Selama penyimpanan 0 hari nilai $a_{w}$ perlakuan $Y R$, YRPP, dan YRPF memiliki nilai $a_{w}$ lebih rendah dari perlakuan jenis $Y$, sedangkan selama penyimpanan 5 sampai 15 hari terjadi penurunan nilai $\mathrm{a}_{\mathrm{w}}$ pada keempat perlakuan jenis yogurt kecuali pada penyimpanan 10 hari pada jenis $Y$ dan YR (Tabel 2).

Lebih rendahnya nilai $a_{w}$ pada penyimpanan 0 hari menunjukkan bahwa penambahan ekstrak rosella memberikan pengaruh yang nyata terhadap nilai $a_{w}$ yang diduga karena kelopak bunga rosella mengandung serat yang mempunyai kemampuan untuk menyerap air bebas (Marsono, 1996). Kandungan serat pada kelopak bunga rosella adalah sebesar 2,4 \% (Winarti, 2008). Penurunan nilai $\mathrm{a}_{\mathrm{w}}$ selama penyimpanan diduga karena kandungan air bebas dalam yogurt digunakan oleh BAL untuk bertahan hidup sehingga kandungan air bebasnya semakin berkurang, sedangkan peningkatan nilai $a_{w}$ pada penyimpanan 10 hari untuk jenis yogurt $Y$ dan $Y R$ diduga karena terbentuknya air bebas sebagai akibat degradasi molekul-molekul pada bahan pangan dan metabolisme respirasi mikroorganisme umumnya diikuti dengan pelepasan air yang berakibat pada peningkatan nilai $a_{w}$ bahan pangan (Buckle et al., 1987).

\section{Karakteristik Nilai $\mathrm{pH}$}

Tabel 3 menunjukkan nilai pH keempat perlakuan jenis yogurt selama penyimpanan 15 hari. Nilai pH pada keempat jenis yogurt secara nyata dipengaruhi oleh perlakuan jenis yogurt dan lama penyimpanan 15 hari $(P<0,05)$. Namun interaksi antar keduanya tidak memberikan pengaruh terhadap nilai $\mathrm{pH}$ yogurt.

Nilai $\mathrm{pH}$ pada keempat jenis yogurt berkisar 3,68 sampai 4,19. Yogurt $Y$ memperoleh nilai $\mathrm{pH}$ tertinggi dan YRPP memperoleh nilai terendah. Sedangkan nilai $\mathrm{pH}$ YR nampak lebih tinggi dari kedua perlakuan yogurt rosella probiotik. Hal tersebut mengindikasikan bahwa penggunaan bakteri probiotik $L$. plantarum IIA-1A5 dan $L$. fermentum B111K memberikan pengaruh terhadap nilai $\mathrm{pH}$ yogurt melalui proses fermentasi yang lebih cepat. Rendahnya nilai $\mathrm{pH}$ pada jenis yogurt rosella probiotik L. plantarum IIA-1A5 diduga disebabkan karena aktivitas bakteri selama proses fermentasi yang berpengaruh terhadap peningkatan jumlah asam organik yang merupakan hasil metabolisme dari bakteri asam laktat. Proses fermentasi yang melibatkan bakteri asam laktat memiliki ciri khas yaitu terakumulasimya metabolit sekunder yang berupa asam organik yang dihasilkan selama proses fermentasi berlangsung yang disertai dengan penurunan nilai pH (Mani Lopez et al., 2014). Rendahnya nilai $\mathrm{pH}$ pada jenis yogurt rosella probiotik $L$. plantarum IIA-1 A5 sejalan dengan penelitian Kapitula et al., (2008) yang menyatakan bahwa selama penyimpanan selama 21 hari pada yogurt menggunakan bakteri probiotik $L$. Plantarum, memiliki nilai yang lebih rendah dari yogurt menggunakan $L$. fermentum.

Penelitian Retnowati et al., (2014) menyatakan bahwa nilai $\mathrm{pH}$ yogurt yang menggunakan bakteri Lactobacillus casei dan L. plantarum dan sari buah kurma dapat menghasilkan nilai $\mathrm{pH}$ berkisar 3,80 sampai 4,10 . Selain penggunaan bakteri probiotik, penambahan ekstrak rosella memberikan pengaruh terhadap nilai $\mathrm{pH}$ yogurt melalui keasaman yang terkandung dalam ekstrak rosella. Nilai $\mathrm{pH}$ yang dimiliki ekstrak rosella adalah 2,49. Kandungan asam yang terkandung dalam ekstrak rosella diduga meningkatkan keasaman yogurt. Hal tersebut sejalan dengan penelitian Adam et al., (2011) bahwa nilai pH yang diperoleh pada yogurt dengan penambahan ekstrak rosella memiliki nilai $\mathrm{pH}$ yang lebih rendah dari yogurt tanpa penambahan rosella yaitu berkisar 3,50 sampai 3,80.

Lama penyimpanan memberikan pengaruh penurunan terhadap nilai $\mathrm{pH}$ yogurt pada penyimpanan 5 hari dan stabil dari penyimpanan 5 hari sampai 15 hari. Penurunan nilai $\mathrm{pH}$ tersebut dikarenakan selama penyimpanan 5 hari proses fermentasi oleh bakteri asam laktat masih terus berjalan sehingga diperoleh $\mathrm{pH}$ yang menurun. Selama penyimpanan 5 hari sampai 15 hari nilai $\mathrm{pH}$ yogurt nampak stabil, dan kestabilan nilai $\mathrm{pH}$ yogurt diduga karena telah selesainya proses fermentasi oleh bakteri asam laktat sehingga pada saat penyimpanan tidak terjadi penurunan $\mathrm{pH}$. Selain itu, 
bakteri asam laktat berada pada fase stationer yang merupakan fase dimana antara pertumbuhan dan kematian bakteri asam laktat seimbang sehingga jumlah keseluruhan bakteri yang hidup akan tetap. Hasil ini sejalan dengan hasil penelitian yang dilakukan Ihsan et al., (2017) yang menyatakan bahwa nilai $\mathrm{pH}$ yogurt sinbiotik dengan menggunakan tepung gembili dapat mengalami penurunan saat disimpan pada suhu $4^{\circ} \mathrm{C}$ dari penyimpanan hari ke-2 sampai penyimpanan hari ke- 6 dan mulai stabil pada penyimpanan hari ke-8 sampai hari ke-14.

\section{Karakteristik Total Asam Tertitrasi}

Tabel 4 menunjukkan bahwa perlakuan jenis yogurt dan lama penyimpanan memberikan pengaruh yang nyata terhadap nilai total asam tertitrasi (TAT), namun tidak memberikan pengaruh terhadap interaksi antar jenis yogurt dan lama penyimpanan. Nilai TAT pada yogurt merupakan salah satu indikator keasaman yang umumnya berbanding terbalik dengan nilai $\mathrm{pH}$. Penurunan nilai $\mathrm{pH}$ terjadi seiring dengan peningkatan nilai TAT. Nilai TAT yang diperoleh dari keempat perlakuan jenis yogurt berbanding terbalik dengan nilai $\mathrm{pH}$ yang diperoleh, yogurt YRPP memiliki nilai $\mathrm{pH}$ terendah dan perlakuan jenis yogurt $Y$ memiliki nilai $\mathrm{pH}$ tertinggi. Sebaliknya nilai TAT tertinggi diperoleh pada yogurt YRPP dan terendah diperoleh pada perlakuan jenis $Y$.

Kadar TAT tertinggi ditunjukkan oleh YRPP dengan rata-rata $2,07 \%$. Hal tersebut menunjukkan bahwa $L$. fermentum B111K memberikan pengaruh terhadap peningkatan nilai TAT yogurt melalui banyaknya jumlah asam laktat yang dihasilkan selama proses fermentasi berlangsung, selama proses fermentasi bakteri asam laktat menghasilkan metabolisme primer berupa asam laktat dan metabolit sekunder berupa asam-asam organik (Adam dan Andy, 2011).

Selama penyimpanan 15 hari, nilai TAT mengalami peningkatan. Peningkatan tertinggi diperoleh pada penyimpanan 15 hari yaitu 1,95\%. Hasil tersebut sesuai dengan hasil penelitian yang dilakukan Ihsan (2017) bahwa nilai TAT yogurt sinbiotik menggunakan tepung gembili mengalami kenaikan selama penyimpanan 14 hari dari 1,25\% menjadi 2,40\%. Dalam 15 hari penyimpanan, nilai rataan TAT untuk keempat perlakuan jenis yogurt sesuai batas maksimal Standar Nasional Indonesia (2009), yaitu $2 \%$.

\section{Karakteristik Total Bakteri Asam Laktat}

Pengujian total bakteri asam laktat dilakukan untuk mengetahui kemampuan hidup bakteri asam laktat

Tabel 4 Nilai TAT yogurt selama penyimpanan suhu dingin

\begin{tabular}{lccccc}
\hline \multirow{2}{*}{$\begin{array}{l}\text { Pama } \\
\text { kenyimpanan Hari }\end{array}$} & Y & YR & YRPP & Rata-rata \\
\cline { 2 - 5 } & & & & YRPF & \\
\hline 0 & $1,18 \pm 0,40$ & $1,54 \pm 0,09$ & $1,88 \pm 0,19$ & $1,60 \pm 0,08$ & $1,55 \pm 0,19^{\mathrm{C}}$ \\
5 & $1,37 \pm 0,08$ & $1,60 \pm 0,09$ & $1,82 \pm 0,05$ & $1,55 \pm 0,03$ & $1,58 \pm 0,06^{\mathrm{C}}$ \\
10 & $1,30 \pm 0,05$ & $1,64 \pm 0,17$ & $2,15 \pm 0,11$ & $1,85 \pm 0,08$ & $1,74 \pm 0,10^{\mathrm{b}}$ \\
15 & $1,42 \pm 0,08$ & $1,77 \pm 0,16$ & $2,44 \pm 0,08$ & $2,18 \pm 0,06$ & $1,95 \pm 0,09^{\mathrm{a}}$ \\
\hline Rata-rata & $1,32 \pm 0,15^{\mathrm{d}}$ & $1,64 \pm 0,12^{\mathrm{C}}$ & $2,07 \pm 0,10^{\mathrm{a}}$ & $1,79 \pm 0,06^{\mathrm{b}}$ & \\
\hline
\end{tabular}

Tabel 5 Nilai total bakteri asam laktat yogurt selama penyimpanan suhu dingin

\begin{tabular}{|c|c|c|c|c|c|}
\hline \multirow{2}{*}{$\begin{array}{l}\text { Lama } \\
\text { Penyimpanan } \\
\text { Hari ke- }\end{array}$} & \multicolumn{4}{|c|}{ Perlakuan Yogurt (Log CFU/ml) } & \multirow[t]{2}{*}{ Rata-rata } \\
\hline & $\mathrm{Y}$ & YR & YRPP & YRPF & \\
\hline 0 & $10,0 \pm 0,32$ & $10,1 \pm 0,21$ & $10,3 \pm 0,29$ & $10,0 \pm 0,19$ & $10,1 \pm 0,25^{\mathrm{a}}$ \\
\hline 5 & $10,1 \pm 0,12$ & $9,76 \pm 0,20$ & $10,0 \pm 0,27$ & $10,1 \pm 0,54$ & $10,0 \pm 0,28^{a b}$ \\
\hline 10 & $9,96 \pm 0,43$ & $9,69 \pm 0,20$ & $9,99 \pm 0,28$ & $9,88 \pm 0,26$ & $9,88 \pm 0,29^{b c}$ \\
\hline 15 & $10,0 \pm 0,02$ & $9,74 \pm 0,21$ & $9,43 \pm 0,21$ & $9,72 \pm 0,04$ & $9,72 \pm 0,128^{c}$ \\
\hline Rata-rata & $9,99 \pm 0,22$ & $9,78 \pm 0,21$ & $9,93 \pm 0,26$ & $9,94 \pm 0,26$ & \\
\hline
\end{tabular}

Tabel 6 Nilai kolesterol terasimilasi selama penyimpanan suhu dingin

\begin{tabular}{|c|c|c|c|c|}
\hline \multirow{2}{*}{$\begin{array}{l}\text { Lama } \\
\text { Penyimpanan Hari } \\
\text { ke- }\end{array}$} & \multicolumn{4}{|c|}{ Perlakuan Yogurt } \\
\hline & $\bar{Y}$ & YR & YRPP & YRPF \\
\hline \multicolumn{5}{|c|}{ Kolesterol Terasimilasi $(\mu \mathrm{g} / \mathrm{ml})$} \\
\hline 0 & $2,28 \pm 0,17^{\mathrm{h}}$ & $6,29 \pm 1,67^{\mathrm{cd}}$ & $9,29 \pm 0,51^{a}$ & $8,37 \pm 1,91^{\mathrm{ab}}$ \\
\hline 5 & $1,62 \pm 0,27^{\mathrm{h}}$ & $4,31 \pm 0,88^{\mathrm{fg}}$ & $7,05 \pm 1,21^{\mathrm{bc}}$ & $7,46 \pm 0,83^{b c}$ \\
\hline 10 & $1,50 \pm 0,38^{h}$ & $2,80 \pm 0,61^{g h}$ & $4,90 \pm 0,03^{\operatorname{def}}$ & $6,16 \pm 1,13^{\text {cde }}$ \\
\hline 15 & $1,21 \pm 0,14^{\mathrm{h}}$ & $2,11 \pm 0,36^{\mathrm{h}}$ & $2,00 \pm 0,33^{h}$ & $4,59 \pm 0,56^{\mathrm{ef}}$ \\
\hline \multicolumn{5}{|c|}{ Persentase Kolesterol Terasimilasi (\%) } \\
\hline 0 & $6,60 \pm 0,46^{\dagger}$ & $19,4 \pm 5,12^{c}$ & $28,6 \pm 4,56^{a}$ & $25,4 \pm 3,25^{a b}$ \\
\hline 5 & $6,61 \pm 1,82^{\dagger}$ & $17,8 \pm 3,00^{\mathrm{cd}}$ & $22,1 \pm 3,12^{\mathrm{bc}}$ & $21,8 \pm 1,98^{b c}$ \\
\hline 10 & $6,47 \pm 1,72^{f}$ & $12,5 \pm 2,57^{\mathrm{e}}$ & $14,9 \pm 3,39^{\mathrm{de}}$ & $19,0 \pm 3,05^{c d}$ \\
\hline 15 & $5,77 \pm 1,42^{\dagger}$ & $7,47 \pm 1,26^{\dagger}$ & $10,5 \pm 3,01^{\text {ef }}$ & $15,7 \pm 3,55^{d}$ \\
\hline
\end{tabular}

Keterangan untuk Tabel 4-6: Angka pada kolom atau baris yang sama dan diikuti huruf berbeda menunjukkan berbeda nyata $(P<0,05)$. $Y$ adalah yogurt tanpa penambahan ekstrak rosella (Hibiscus sabdariffa), YR adalah yogurt dengan penambahan ekstrak rosella, YRPP adalah yogurt ekstrak rosella probiotik dengan L.plantarum IIA-1A5, dan YRPF adalah yogurt rosella probiotik dengan L. fermentum B111K. 
(BAL) selama penyimpanan (Tabel 5). Bakteri asam laktat merupakan bakteri yang masuk dalam kelompok bakteri yang mampu mengubah laktosa menjadi asam laktat. Laktosa digunakan sebagai sumber karbon untuk pertumbuhan maupun sebagai sumber energi bagi bakteri. Laktosa dalam susu ditransfer ke dalam sel oleh enzim permease, kemudian oleh enzim laktase atau phospho-galaktosidase diubah menjadi galaktosa dan glukosa. Glukosa yang terbentuk, selanjutnya oleh bakteri asam laktat dimetabolisme menjadi asam laktat (Tamime \& Deeth, 1989). Nilai total BAL nyata dipengaruhi oleh lama penyimpanan suhu $4^{\circ} \mathrm{C}(\mathrm{P}<0,05)$, namun tidak dipengaruhi oleh perlakuan jenis yogurt dan tidak terjadi interaksi antar keduanya $(P>0,05)$. Selama penyimpanan 0 dan 5 hari nilai total $B A L$ yang diperoleh lebih tinggi dari penyimpanan 10 dan 15 hari yang disebabkan karena masih terpenuhi nutrisi bagi bakteri asam laktat untuk tumbuh dan berkembang karena masih tersedianya substrat (Nofrianti et al., 2013; Retnanti et al., 2009).

Selama penyimpanan 10 hari sampai 15 hari, nilai total BAL mengalami penurunan dari 10,0 log CFU/ml menjadi 9,88 log CFU/ml. Penurunan tersebut disebabkan karena pertumbuhan BAL sudah mencapai fase stasioner yang merupakan fase keseimbangan antara laju pertumbuhan dan kematian bakteri asam laktat di dalam yogurt. Penelitian Fatmawati et al., (2013) menunjukkan bahwa selama penyimpanan 14 hari jumlah total BAL pada yogurt menggunakan lima bahan dasar susu secara umum mengalami penurunan yang disebabkan karena pertumbuhan bakteri telah mencapai fase stationer dan bahkan akan menuju fase kematian sehingga terdapat pengurangan jumlah sel mikroba. Soeharto el al., (2017) juga menyatakan bahwa selama penyimpanan 15 hari terjadi penurunan nilai total bakteri asam laktat yang disebabkan karena adanya perubahan kadar asam laktat yang dihasilkan selama masa penyimpanan.

Syarat mutu yogurt yang ditentukan oleh SNI 01 2981-2009 yaitu minimal sebesar $10^{7} \mathrm{CFU} / \mathrm{ml}$. Nilai total BAL pada keempat perlakuan berkisar 9,88-10,0 log CFU/ml. Nilai tersebut menunjukkan bahwa nilai total BAL keempat perlakuan dengan lama penyimpanan hari ke-0 sampai hari ke-15 sesuai dengan Standar Nasional Indonesia (2009) karena nilai yang diperoleh melebihi nilai yang ditentukan yaitu $10^{7} \mathrm{CFU} / \mathrm{ml}$.

\section{Kemampuan Asimilasi Kolesterol Yogurt}

Pengujian kemampuan dalam mengasimilasi kolesterol ini dilakukan atas dasar dugaan bahwa YRPP dan YRPF memiliki potensi dalam mengasimilasi kolesterol dilihat dari kemampuannya dalam mengasimilasi kolesterol selama penyimpanan 15 hari. Pada Tabel 6 dapat dilihat bahwa selama penyimpanan YRPP dan YRPF memiliki nilai asimilasi kolesterol lebih tinggi dari yogurt $Y$ dan $Y R$, sedangkan $Y R$ memiliki kemampuan asimilasi kolesterol lebih tinggi dari $Y$. Hal tersebut menunjukkan bahwa jenis perlakuan bakteri probiotik L. plantarum IIA-1A5, L. fermentum B111K dan penambahan ekstrak rosella, serta interaksi antar perlakuan jenis yogurt dan lama penyimpanan memberikan pengaruh yang nyata terhadap nilai kolesterol terasimilasi dan persentase kolesterol terasimilasi yogurt $(\mathrm{P}<0,05)$.

Tingginya nilai kolesterol terasimilasi dan persentase kolesterol terasimilasi pada YRPP YRPF pada penyimpanan 0 hari disebabkan karena adanya kemampuan asimilasi kolesterol oleh bakteri $L$. plantarum IIA-1A5 dan probiotik $L$. fermentum B111K. Burhan et al., (2017) menyatakan bahwa bakteri $L$. plantarum IIA-1A5 dan probiotik $L$. fermentum B111K memiliki kemampuan asimilasi kolesterol dalam media MRSB. Adanya kemampuan bakteri probiotik dalam mengasimilasi kolesterol sesuai dengan hasil penelitian Maryati (2015) yang menyatakan bahwa bakteri probiotik L. plantarum 1-S27202 dan L. fermentum S21209 memiliki kemampuan dalam menurunkan kolesterol yang melibatkan asimilasi kolesterol. Selain itu, Handayani et al., (2012) menambahkan bahwa bakteri probiotik $L$. plantarum memiliki potensi dalam mengasimilasi kolesterol pada produk "okara drink" sebesar $2,69 \%$.

Mekanisme asimilasi kolesterol oleh bakteri probiotik berkaitan dengan jumlah total BAL yang dihasilkan (Burhan et al., 2017). Nilai total BAL yang dihasilkan dalam penelitian ini tidak berbeda nyata, namun dari bakteri yang digunakan bakteri $L$. plantarum IIA-1A5 dan $L$. fermentum B111K yang memiliki kemampuan dalam mengasimilasi kolesterol paling tinggi karena bakteri L. bulgaricus dan $S$. thermophillus hanya mampu mengasimilasi kolesterol sebesar $4 \%$ (Bouras, 2006). Selain itu, kemampuan mengasimilasi kolesterol juga dipengaruhi kemampuan pengikatan kolesterol oleh BAL. Pengikatan kolesterol oleh BAL disebabkan karena ketebalan peptidoglikan penyusun dinding sel. Dinding sel mampu mengikat dan menyerap kolesterol ke dalam selnya yang digunakan untuk pembentukan membran sel (Kumar et al., 2012).

Ekstrak rosella juga memiliki peran dalam mengasimilasi kolesterol. Di dalam ekstrak rosella terdapat komponen seperti fenolik yang memiliki sifat antioksidan dan steroid (Hanifah et al., 2015). AliBradeldin et al., (2005) juga menyatakan bahwa kandungan fenol pada kelopak bunga rosella berupa antosianin seperti delphinidin-3-glucoside, sambubioside, dan cyanidin-3-sambubioside, flavonoid seperti gossypetin, hibiscetin, dan glikosida berupa protocatechuic acid, eugenol, dan sterol seperti $\beta$ sitosterol dan ergoesterol. Mekanisme ekstrak rosella dalam mengasimilasi kolesterol secara in vitro belum sepenuhnya jelas namun secara in vivo diduga efek hipokolesterolemik pada ekstrak rosella disebabkan karena kandungan antosianin, $\beta$-sitosterol dan pektin yang mampu mempercepat katabolisme kolesterol serta adanya efek inhibisi pada pektin terhadap enzim HMG CoA reduktase (Brewer, 2004). Suhartatik et al., (2009) menyatakan bahwa ekstrak rosella yang difermentasikan dalam minuman kombucha mampu menurunkan kolesterol akibat tingginya aktivitas antioksidan seperti antosianin dan pektin di dalam ekstrak rosella. 
Selama penyimpanan 5 hari nilai kolesterol terasimilasi mengalami penurunan diikuti menurunnya jumlah total bakteri asam laktat selama penyimpanan yang disebabkan berkurangnya nutrisi yang terdapat dalam yogurt. Penurunan nilai asimilasi kolesterol pada penyimpanan 5 hari juga ditunjukkan dengan terjadinya perubahan warna yogurt pada perlakuan menggunakan ekstrak rosella yang kemungkinan disebabkan karena pengaruh $\mathrm{pH}$ yogurt. Herawati et al. (2012) menyatakan selama penyimpanan 21 hari pada suhu dingin, senyawa antioksidan yang terdapat di dalam minuman fungsional berbasis ekstrak buah naga, ekstrak rosella dan ekstrak buah salam dapat mengalami penurunan akibat adanya pengaruh lama penyimpanan suhu dingin yang ditunjukkan dengan adanya perubahan warna. Perubahan warna terjadi karena $\mathrm{pH}$ lingkungan yang menyebabkan kandungan antosianin menjadi tidak stabil. Antosianin umumnya bersifat asam dan lebih stabil dalam kondisi asam (Widyasanti et al., 2018). Dalam penelitian ini, nilai $\mathrm{pH}$ yogurt menggunakan ekstrak rosella berada pada kisaran 3,63-3,86, dan nilai tersebut menunjukkan kandungan antosianin dapat berkurang akibat nilai pH lingkungan yang kurang asam. Selain $\mathrm{pH}$ terdapat beberapa faktor yang mempengaruhi stabilitas antosianin antara lain adanya modifikasi pada struktur spesifik antosianin (glikosilasi, asilasi dengan asam alifatik atau aromatik), temperatur, cahaya, oksigen, kadar gula, enzim dan pengaruh sulfur oksida (Misrha et al., 2008).

Pada penyimpanan 10 dan 15 hari, nilai kolesterol terasimilasi dan persentase kolesterol tertinggi diperoleh pada YRPF yaitu masing-masing sebesar $4,59 \mu \mathrm{g} / \mathrm{ml}$ dan $25,4 \%$ yang diduga dapat dicapai oleh $L$. fermentum B111K oleh karena bakteri ini lebih tahan terhadap lingkungan yogurt (Syah et al., 2017) dan mampu mengasimilasi kolesterol dibandingkan dengan bakteri probotik L. plantarum IIA-1A5 (Arief et al., 2015).

\section{Kesimpulan}

Kualitas fisik, kimiawi dan mikrobiologi yogurt selama 15 hari penyimpanan masih dapat dikatakan baik dan layak untuk dikonsumsi. Kemampuan asimilasi kolesterol pada yogurt rosella probiotik menggunakan Lactobacillus plantarum IIA-1A5 dan yogurt rosella probiotik menggunakan Lactobacillus fermentum B111K lebih tinggi dibandingkan yogurt dan yogurt rosella serta terjadi penurunan kemampuan asimilasi pada keempat jenis yogurt selama penyimpanan 15 hari.

\section{Ucapan Terima Kasih}

Penulis mengucapkan terimakasih kepada DP2M atas bantuan yang telah diberikan dalam Hibah Pasca dengan Nomor : 129/SP2H/PTNBH/DRPM/2018.

\section{Daftar Pustaka}

Association of Official Analytical Chemist (AOAC) Official Methods of Analysis. 2005. United States of America.

Standar Nasional Indonesia (SNI) 2981-2009. 2009. Yogurt. Badan Standarisasi Nasional. Jakarta.
Adam, M.H., Andy. 2011. Penambahan ekstrak bunga rosella (Hibiscus sabdariffa Linn) untuk peningkatan kualitas yogurt. Jurnal Agrisistem 9(2):96-105.

Ali-Bradeldin, H., Al-Wahel, N., Gerald, B. 2005. Phytochemical, pharmacological, and toxicological aspects of Hibiscus sabdariffa L. A Review Phytotheraphy Research 19:369-375. DOI:10.1002/ptr.1628.

Arief, I.I., Jenie, B.S.L., Astawan, M., Fujiyama, K., Witarto, A.B. 2015. Identification and probiotic characteristics of lactic acid bacteria isolated from Indonesian local beef. Asian Journal Animal Science 9(1):25-36. DOI: 10.3923/ ajas.2015.25.36.

Arief, II., Budiman, C., Hanifah, R., Soenarno, M.S. 2016. Antihypertensive potency of goat milk yoghurt supplemented by probiotic and roselle extract. International Journal Sciences Basic and Applied Research 30(4):207-214.

Belitz, H.D., Grosch, W., Schieberle, P. 2009. Food Chemistry 4th Revised and Extended Edition. Springer Verlag:Berlin, Germany. ISBN: 9783540699330.

Bouras, A.D. 2006. Assimilation (in vitro) of cholesterol by yogurt bacteria. Original Article Annals of Agricultural and Environmental Medicine 13:4953.

Bourlioux, P., Koletzko, B., Guarner, F., Braesco, V. 2003. The intestine and its microflora are partners for the protection of the host: report on the Danone Symposium "The Intelligent Intestine". American Journal of Clininical Nutrition 7:675-683. DOI: 10.1093/ajcn/78.4.675.

Brewer, H.B. 2004. Increasing HDL cholesterol levels. New England Journal of Medicine 15:350.DOI: 10.1056/NEJMp048023.

Buckle, K.A., Edwards, R.A., Fleet, G.H., Wotton, M. 1987. Ilmu Pangan. Penerjemah Hari Purnomo dan Adiono. Universitas Indonesia Press, Jakarta.

Burhan, H., Priyambada S.A., Taufik, E., Arief, I.I. 2017. Potential of lactic acid bacteria isolated from dangke and Indonesian beef as hypocholesterolaemic agent. Jurnal Media Peternakan 40(2):136-142. DOI: 10.5398/medpet. 2017.40.2.136.

Burhan, B. 2008. Kefir Minuman Susu Fermentasi dengan Segudang Khasiat untuk Kesehatan. Cetakan I, Gramedia Pustaka Utama, Jakarta.

Donkor, O.N., Henriksson, A., Vasiljevic T., Shah N.P. 2006. Effect of acidification on the activity of probiotics in yoghurt during cold storage. International Dairy Journal 16:1181-1189.DOI: 10.1016/j.idairyj.2005.10.008.

Fatmawati, U., Prasetyo, F.I., Supia, T.A.M., Utami, A.N. 2013. Karakteristik yogurt yang terbuat dari berbagai jenis susu dengan penambahan kultur campuran Lactobacillus bulgaricus dan Streptococcus thermophillus. Jurnal Bioedukasi 6(2):1-9. DOI:10.20961/ bioedukasiuns.v62.2644. 
Freed, J.P. 1994. Kamus Kedokteran Dorland, Terjemahan: Harjono RM et al. 26th ed, Buku Kedokteran EGC. Jakarta.

Hanifah, R., Arief, I.I., Budiman, C. 2015. Antimicrobial activity of goat milk yoghurt with addition of a probiotic Lactobacillus acidophilus IIA - 2B4 and roselle (Hibiscus sabdariffa L) extract. International Food Research Journal 23(6):26382645.

Herawati, N., Sukatiningsih, Windrati, W.S. 2012. Pembuatan minuman fungsional berbasis ekstrak kulit buah naga merah (Hylocereus polyrhizus), rosela (Hibiscus sabdariffa L.) dan buah salam (Syzygium polyanthum wigh walp). Jurnal Agrotech 6(1):40-50.

Ihsan, R.Z., Cakrawati, D., Handayani, M.N., Handayani, S. 2017. Penentuan umur simpan yoghurt sinbiotik dengan penambahan tepung gembili modifikasi fisik. Jurnal Edufortech 2(1):1-6.

Ishmayana, S., Juanda, A., Suprijana, O., Djajasoepana, S., Rachman, I.S.D.R. 2015. Pengaruh konsumsi yogurt yang dibuat dengan kultur dua bakteri (Streptococcus thermophillus dan Lactobacillus bulgaricus) dan tiga kultur bakteri (Streptococcus thermophillus, Lactobacillus acidhophillus dan Lactobacillus bulgaricus) terhadap kadar kolesterol serum darah tikus. Jurnal Chimica et Natura Acta 3(3):94-99.

Kapitula, M.M., Klebukowska, L., Kornacki, K. 2008. Evaluation of the possible use of potentially probiotic Lactobacillus strains in dairy product. International Journal of Dairy Technology 61(2):165-169. DOI:10.1111/j.1471-0307.2008. 00392.x

Kumar, M., Nagpal, R., Kumar, R., Hemalatha, R., Verma,V., Kumar, A., Chakraborty, C., Singh, B., Marotta, F., Jain, S., Yadav, H. 2012. Cholesterollowering probiotics as potential biotherapeutics for metabolic diseases. Experimental Diabetes Research 14, 902-917. DOI: 10.1155/2012/ 902917.

Malaka, R. 2010. Eksopolisakarida bakteri starter kultur susu fermentasi sebagai sumber polisakarida harapan di masa depan. Orasi IImiah. Universitas Hasanudin Makassar. DOI: 10.13140/RG.2.2.23826.04803

Marsono, Y. 1996. Dietary Fiber dalam Makanan Fungsional. Makalah Work Shop, PAU Pangan dan Gizi, Universitas Gadjah Mada, Yogyakarta

Maryati, Y., Nuraida, L., Hariyadi, R.D. 2016. Penurunan kolesterol secara in vitro oleh isolat bakteri asam laktat dengan keberadaan oligosakarida Jurnal Agritech 36(2):196-205. DOI:10.22146/agritech.12865.

Nielsen, S.S. 2003. Food Analysis Third Edition. Kluwer Academic/Plenum Publishers, New York (US).

Nofrianti, R., Azima, F., Eliyasmi. 2013. Pengaruh penambahan madu terhadap mutu yoghurt jagung. Jurnal Aplikasi Teknologi Pangan 2(2): 60-67.
Novasina. 2010. Guideline book for running using viskotester VT-04F. Pfaffikon, Switzerland.

Octavia, Z.F., Djamiatun. K., Suci, N. 2017. Pengaruh pemberian yogurt sinbiotik tepung pisang tandung terhadap profil lipid tikus sindrom metabolik. Jurnal Gizi Klinik Indonesia 13(4):159169.DOI:10.22146/ijen.19369

Pelezar, M.J., Chan E.C.S. 2007. Dasar-dasar Mikrobiologi Jilid I. Terjemahan Hadioetomo, R.S., Imas, T., Tjitrosomo, S.S., Angka, S.L. Indonesia Press, Jakarta.

Retnowati, P.A., Kusnadi, J. 2014. Pembuatan minuman probiotik sari buah kurma (Phoenix dactylifera) dengan isolat Lactobacillus casei dan Lactobacillus plantarum, Jurnal Pangan dan Agroindustri 2(2):70-81.

Rion. 2015. Guideline book for running using $a_{w}$ meter Novasina ms1 Set-aw. Osaka, Japan.

Rose, A. H. 1989. Fermented Food in Economic Microbiology. Academic Press Inc., London.

Setiawan, D.I., Tjahyono, K., Afifah, D.N. 2016. Pemberian kecambah kacang kedelai terhadap kadar malondialdehid (MDA) dan superoxide dismutase (SOD) tikus Sprague Dawley hiperkolesterolemia, Jurnal Gizi Klinik Indonesia 13(1):20-26. DOI:10.22146/ijcn.22815.

Suhartatik, N., Karyantina, M., Purwanti, I.P. 2009. Kombucha Rosella (Hibiscus sabdariffa Linn) dan kemampuannya sebagai antihiperkolesterolemia, Jurnal Agritech 29(1):34-35. DOI:10.22146/agritech.9758.

Suharto, E.L.S., Arief, I.I., Taufik, E. 2017. Quality and activity of yogurt supplemented with roselle during cold stroge, Journal Media Peternakan 39(2):8289.DOI:10.5398/medpet.2016.39.2.82.

Syah, S.P., Sumantri, C., Arief, I.I., Taufik, E. 2017. Karakteristik minuman whey yang difermentasikan dengan bakteri asam laktat indigenus asal dangke. Jurnal Teknologi dan Industri Pangan 28(2):129-138. DOI: 10.6066/ jtip.2017.28.2.129

Thai Agriculture Standar (TAS). 2008. Raw Goat Milk. National Bureau of Agriculture Commodity and Food Standars, Ministry of Agriculture and Cooperative. ICS 67.100.01. Published in the Royal Gazette, 125(139). Thailand.

Tomaro-Duchesneau, C., Jones, M.L., Shah,. P., Jain S., Saha., Prakash. S. 2014. Cholesterol assimilation by Lactobacillus probiotic bacteria: an in vitro investigation. Journal of Biomedical Research International 1-9. DOI:10.1155/2014/ 380316.

Tsai, P.J., Melntosh, J., Pearce, P., Camden, B., Jordan, B.R. 2008. Anthocyanin and antioxidant capacity in roselle (Hibiscus sabdariffa $\mathrm{L}$ ) extract. Journal Food Research International 35:351-356. DOI:10.1016/S0963-9969(01)00129-6

Tuomola, E., Crittenden, R., Playne, M., Isolauri, E., Salminen, S. 2001. Quality assurance criteria for probiotic bacteria. American Journal Clinical 
Nutrition 73(suppl):393S-398S. DOI: 10.1093/ ajcn/73.2.393s

Wahyudi, A., S. Samsundari. 2008. Bugar dengan Susu Fermentasi. Universitas Muhammadiyah Malang Press, Malang.

Widyasanti, A., Nurlaily, N., Wulandari E. 2018. Karakteristik fisikokimia antosianin ekstrak kulit buah naga merah menggunakan metode
UAE. Jurnal Ilmiah Rekayasa Pertanian dan Biosistem 6(1):27-38. DOI:10.29303/jrpb.v6i1.63

Winarti, S. 2008. Pemanfaatan buah mengkudu (Morinda citrifolia) dan kelopak bunga rosella (Hibiscus sabdariffa Linn) untuk pembuatan fruit leather. Jurnal Agritech 28(1):22-27.

Winarti, S. 2010. Makanan Fungsional. Graha IImu, Yogyakarta. 